\title{
Age-dependent changes in the exocytotic efficacy in Kir6.2 ablated mouse pancreatic $\beta$-cells
}

\author{
Ernest Beaudelaire Tsiaze ${ }^{1}$, Ya-Chi Huang ${ }^{2}$, Lidija Križančić Bombek ${ }^{3}$, Shi-Bing Yang ${ }^{4}$, \\ Marko Jevšek $^{3}$, Susumu Seino ${ }^{5}$, Marjan Slak Rupnik ${ }^{1,3^{*}}$ \\ ${ }^{1}$ European Neuroscience Institute, Göttingen, Germany \\ ${ }^{2}$ Institute of Medical Science, University of Toronto, Toronto, Canada \\ ${ }^{3}$ Institute of Physiology, Faculty of Medicine, University of Maribor, Maribor, Slovenia \\ ${ }^{4}$ Howard Hughes Medical Institute, San Francisco, USA \\ ${ }^{5}$ Division of Diabetes and Endocrinology, Department of Internal Medicine, Kobe University Graduate School of Medicine, Kobe, Japan \\ Email: ${ }^{*}$ marjan.rupnik@uni-mb.si
}

Received 11 June 2012; revised 15 July 2012; accepted 2 August 2012

\section{ABSTRACT}

In this study, we aimed to examine the electrophysiological properties of $\beta$-cells in Kir6.2 ${ }^{-/}$mice using fresh pancreatic tissue slice preparation. This preparation is advantageous since it preserves socio-cellular context of the $\beta$-cells. Using this novel approach we revisited basic morphology and used whole-cell patch-clamp to study electrical excitability as well as to assess the modulation of the late steps of the exocytotic activity of $\beta$-cells by cytosolic $\left[\mathrm{Ca}^{2+}\right]$ changes in control and Kir6.2 ${ }^{-/-}$mice. We found that young Kir6.2 ${ }^{-/-}$mice (2 4 weeks old) were hypoglycaemic while aged Kir6. ${ }^{-/-}$ mice (5 - 60 weeks old) were normo- or even hyperglycaemic. Membrane capacitance measurements showed more efficient $\mathrm{Ca}^{2+}$-secretion coupling in young Kir6.2 ${ }^{-/-}$mice, but this coupling is significantly reduced in older Kir6. $2^{-/}$mice. We have found increased exocytotic efficacy induced by repetitive trains of depolarization pulses which may result from higher cytosolic $\left[\mathrm{Ca}^{2+}\right]$ due to hyperexcitability in Kir6.2 ${ }^{-/-}$mice. This condition in turn resulted in the reduced $\beta$-cell number and function in the following weeks. Detailed assessment of the efficacy of $\mathrm{Ca}^{2+}$ dependent exocytosis in $\beta$-cell from Kir6. $2^{-/-}$mice may contribute to our understanding of the pathophysiology of persistent hyperinsulinemia hypoglycemia of infancy (PHHI) and suggest potential alternative therapeutic approaches for PHHI patients.

Keywords: Islets of Langerhans; Insulin; Hyperinsulinism; Persistent Hyperinsulinemia Hypoglycemia of Infancy; Ion Channels; Patch-Clamp Techniques

*Corresponding author.

\section{INTRODUCTION}

In pancreatic $\beta$-cells, ATP-dependent potassium channels $\left(\mathrm{K}_{\mathrm{ATP}}\right)$ have been reported to regulate insulin secretion by coupling the cell metabolism to the membrane excitability [1]. A key stimulus for insulin secretion is an increased blood glucose level that increases cytosolic ATP $\left([\mathrm{ATP}]_{\mathrm{c}}\right)$. However, this change is only a $30 \%$ to $40 \%$ above the basal ATP level [2]. The increase in $[\mathrm{ATP}]_{\mathrm{c}}$ in $\beta$-cells is believed to initiate the stimulus-secretion coupling cascade: promotes closure of $\mathrm{K}_{\mathrm{ATP}}$ channels, membrane depolarization of the $\beta$-cell syncytia and opening of the voltage-activated calcium channels (VACC), together resulting in the elevation of cytosolic calcium and triggering the release of insulin-containing granules [3].

The $\mathrm{K}_{\text {ATP }}$ channel is formed by inward rectifier potassium channel 6.2 (Kir6.2) and sulphonylurea receptor (SUR1) subunits in a 4:4 stoichiometry [4,5]. The four Kir6.2 subunits comprise an inwardly rectifying $\mathrm{K}^{+}$channel while SUR1 subunits are regulatory proteins belonging to $\mathrm{ABC}$ transporter family [6]. SUR1 subunits conglomerate with Kir6.2 subunits in the endoplasmic reticulum and were suggested to chaperon the fully assembled $\mathrm{K}_{\text {ATP }}$ channels to the plasma membrane $[7,8]$. SUR1 subunit also confers $\mathrm{K}_{\mathrm{ATP}}$ channels' response to pharmacological agents such as sulfonylureas and diazoxide [9], primarily defining the sensitivity of the $\mathrm{K}_{\mathrm{ATP}}$ channels to ATP [10].

Human genetic studies have shown that mutations on both proteins forming the $\mathrm{K}_{\mathrm{ATP}}$ channel impair functional insulin release and result in inappropriate serum insulin levels at a given plasma glucose level [11]. Gain of function mutations lead to hypoexcitability and suppress insulin release in neonatal diabetes mellitus (NDM) [1214]. Conversely, loss of function of $K_{\text {ATP }}$ channels leads to a persistent hyperexcitabilty of the $\beta$-cell and results in persistent hyperinsulinaemic hypoglycaemia of in- 
fancy (PHHI) [15-17]. These patients commonly exhibit symptomatic hypoglycaemia soon after birth, are largely unresponsive to $\mathrm{K}_{\mathrm{ATP}}$ channel openers such as diazoxide and often require subtotal $(95 \%)$ resection of the pancreas to alleviate hypoglycaemia [18].

$\mathrm{K}_{\text {ATP }}$ channel-deficient mice have been generated by genetic disruption of Kir6.2 subunit (Kir6.2 ${ }^{-/-}$) [19] which can serve as a PHHI animal model to investigate the role of $\mathrm{K}_{\text {ATP }}$ channels in the glucose-induced insulin-secretion in vivo [19-22].

In this study we originally assessed the electrical and secretory activities in the Kir6. $2^{-/}$mice using a novel fresh pancreatic slice preparation [23], a method that avoids enzymatic and mechanical stress to $\beta$-cells during sample preparation and preserves the functionality and architecture of islets in the slice. Despite the predicted and previously reported hyperexcitability of Kir6. $2^{-/-} \beta$-cells, the mice lacking this protein show an age dependent change in VACC densities and plasma glucose levels. In addition we this is the first report describing a change in exocytotic efficacy of the $\beta$-cells in Kir6. $2^{-/-}$ablated mice. The results of this study contribute to our understanding of the pathophysiology of PHHI in human patients, which may lead towards a consideration of a less radical therapy and management of the PHHI patients.

\section{MATERIALS AND METHODS}

\subsection{Animals}

All animals were kept under standard housing conditions with free access to water and food. Experiments were conducted according to the regulations of our institutional and state committees on animal experiments (ZTE, University of Goettingen, and Faculty of Medicine University of Maribor). Homozygous Kir6. $2^{-/}$mice were maintained in C57/B6 background and wildtype C57/B6 were used as control (Phillips-University Marburg, Germany). Animals were euthanized by $\mathrm{CO}_{2}$ followed by cervical dislocation. Immediately afterwards, blood samples were taken from the tail vein for glucose measurements. Blood glucose concentration was measured using the glucose oxidase method (OneTouch Ultra, Lifescan, USA).

Pancreatic slices were prepared as previously described [23]. Briefly, 2\% gelling agarose (Seaplaque GTG agarose, BMA, Walkersville, Md., USA) melted in warm $\left(37^{\circ} \mathrm{C}\right)$ extracellular solution (ECS) was injected into the pancreatic duct to stabilize the tissue. After injection, the pancreas was cooled immediately with an ice-cold ECS and cut into $140 \mu \mathrm{m}$ thick slices using vibratome (VT $1000 \mathrm{~S}$, Leica, Nussloch, Germany). After slicing, the tissue slices were kept in ice-cold ECS, carbogenated with 95\% oxygen and 5\% carbon dioxide. Prior to electrophysiological experiments, the slices were incubated for at least $30 \mathrm{~min}-$ utes at $32^{\circ} \mathrm{C}$ in carbogenated ECS.

\subsection{Solutions}

Standard extracellular solution (ECS) consisted of the following (in mM): $125 \mathrm{NaCl}, 2.5 \mathrm{KCl}, 26 \mathrm{NaHCO}_{3}, 1.25$ $\mathrm{Na}_{2} \mathrm{HPO}_{4}, 2$ Na-pyruvate, 0.25 ascorbic acid, 3 myo-inositol, 6 lactic acid, $1 \mathrm{MgCl}_{2}$ and $2 \mathrm{CaCl}_{2}$. If not otherwise indicated, the glucose concentration of the ECS was 3 $\mathrm{mM}$. All extracellular solutions were bubbled with carbogen $\left(95 \% \mathrm{O}_{2}, 5 \% \mathrm{CO}_{2}\right)$ for at least 30 minutes to keep the $\mathrm{pH}$ at 7.3 .

Experiments were performed with two different pipette filling solutions. The first intracellular solution (ICS1) was used to measure cellular electrical activity in the currentclamp mode and contained (in $\mathrm{mM}$ ): $132 \mathrm{~K}$-gluconate, $28 \mathrm{KCl}, 10$ HEPES (pH 7.2 with $\mathrm{KOH}$ ), $2 \mathrm{MgCl}_{2}, 0.05$ EGTA and $4 \mathrm{ATPNa}_{2}$. The intracellular solution (ICS2) to measure $\mathrm{Ca}^{2+}$ currents and membrane capacitance $\left(\mathrm{C}_{\mathrm{m}}\right)$ contained (in $\mathrm{mM}$ ): $127 \mathrm{Cs}$-methanesulfonate, $8 \mathrm{CsCl}, 10$ HEPES (pH 7.2 with CsOH), $2 \mathrm{MgCl}_{2}, 0.05$ EGTA, 20 tetraethylammonium (TEA) chloride and $4 \mathrm{ATPNa}_{2}$. The osmolarity of all used solutions was adjusted to $300+/-$ $10 \mathrm{mOsm}$. All chemicals used were purchased from Sigma (USA) unless otherwise indicated.

\subsection{Electrophysiology}

Glass pipettes were pulled on a horizontal pipette puller (P97; Sutter Instruments, USA) from borosilicate glass capillaries (GC150F15; WPI, USA) to a resistance of 2 $4 \mathrm{M} \Omega$ in a KCl-based solution. The perfusion chamber was mounted on an upright microscope (Eclipse E600FN, Nikon, Japan) equipped with a $60 \times$ water immersion objective (CFI Fluor, NA = 1). A CCD camera (Cohu, San Diego, CA, USA) was used for visualization. Fresh pancreas slices were held at the bottom of the recording chamber $(400 \mu 1)$ by a U-shaped platinum frame with a nylonfiber grid and perfused continuously with carbogen-bubbled ECS $\left(30^{\circ} \mathrm{C}-32^{\circ} \mathrm{C}, 1.5 \mathrm{ml} \cdot \mathrm{min}^{-1}\right)$. All experiments were performed in the standard whole-cell patch-clamp mode on a SWAM IIC dual-phase lock-in patch-clamp amplifier (Celica, Ljubljana, Slovenia). Cells from the second or third layer in the islets were used for electrophysiological recording to increase the probability of finding $\beta$-cells. $\beta$-cells were identified by their $\mathrm{Na}^{+}$currents inactivation pattern, the change in membrane potential or spiking electrical activity in the presence of elevated glucose $[24,25]$ as well as the presence of gap junction conductance [26]. Recordings, stimulation, and basic analyses were performed using the WinWCP software (v3.52, John Dempster, University of Strathclyde, UK). The initial $\mathrm{C}_{\text {slow }}$ values were further used for the estimation of the surface area of the patched cells assuming a specific membrane capacitance $\left(\mathrm{C}_{\mathrm{m}}\right)$ of $9 \mathrm{fF} \cdot \mu^{-2}$. All currents were analysed and presented after $\mathrm{P} / \mathrm{N}$ leak current subtraction. To estimate changes in membrane capacitance $\left(\Delta \mathrm{C}_{\mathrm{m}}\right)$, the 
piecewise-linear technique was used (sine wave frequency $1.6 \mathrm{kHz}$, amplitude $11 \mathrm{mV}$ RMS). The deflection of the $\mathrm{C}_{\mathrm{m}}$ trace in response to the $1 \mathrm{pF}$ test pulse was used to calibrate the measured $C_{m}$ values. $C_{m}$, access conductance $\left(\mathrm{G}_{\mathrm{a}}\right)$, membrane current (I) and membrane potential $(\mathrm{V})$ were recorded after filtering at $3 \mathrm{kHz}$ and stored for off-line analysis. These data were transferred to a PC via an A/D converter (PCI-6035E, National Instruments, USA). Cells showing unstable holding currents or a leak conductance larger than $2 \mathrm{nS}$ at basal conditions were excluded from the analysis. For data analysis and figure preparation we used Matlab, Matview (Matlab WinWCP extension, Wise Technologies, Ljubljana, Slovenia), Sigmaplot and Sigmastat (SPSS, Chicago, IL, USA). All values are presented as mean \pm S.E.M and the data were compared by unpaired Student's $t$-test.

\section{RESULTS}

\subsection{Age-Dependent Morphological and Physiological Changes of Pancreatic Islets in Kir6.2 $^{-/-}$Mice}

Despite the genetic ablation of the $\mathrm{K}_{\mathrm{ATP}}$ channel pore, the pancreatic islets in tissue slices obtained from 2 weeks old Kir6. $2^{-/-}$mouse appeared normal with densely packed groups of cells (Figure 1(a), bottom left). However, the islets of Kir $6.2^{-/-}$mice aged 30 weeks and older showed hollow spaces with few or no cells and irregular outline (Figure 1(a), bottom right). Moreover, this apparent change in the cyto-architecture also resulted in a lower yield of successful whole-cell recordings from Kir6. $2^{-/} \beta$-cells at older age. These finding are in agreement with previously published data that both the number and the intensity of insulin immunoreactivity of $\beta$-cells decrease as the Kir6. $2^{-/-}$ mice get older $[19,22]$. In addition, the probability to patch-clamp an $\alpha$-cell in the central part of the islet was higher compared to young mice, also indicating that the population of $\alpha$-cells within the islet has increased as also previously reported [22].

Besides the aforementioned morphological changes some physiological parameters we measured have also changed with the increasing age of the animals. When measuring blood glucose levels, we observed transient hypoglycaemia in young and progressive hyperglycaemia in old Kir6. $2^{-/-}$mice. Figure 1(b) shows randomly measured blood glucose levels in control C57/B6 and Kir6. $2^{-/-}$mice at different ages. Two to four weeks after birth, the Kir6. $2^{-/-}$ mice showed a mild, but significant hypoglycaemia with the mean glucose levels of $5.6 \pm 0.2 \mathrm{mM}(\mathrm{n}=29) \mathrm{com}$ pared to $8.5 \pm 0.2 \mathrm{mM}$ in age matched control mice $(\mathrm{n}=$ $27 ; \mathrm{p}<0.001)$. Similarly to previous reports, the mean glucose level in 5 - 28 weeks old Kir6. $2^{-/ 2}$ mice was comparable to C57/B6 controls with mean glucose level of $8.1 \pm 0.3 \mathrm{mM}$ and $8.3 \pm 0.2 \mathrm{mM}$, respectively $(\mathrm{p}=0.6)$. However, at ages of 30 weeks or older, Kir6. $2^{-/-}$mice became significantly hyperglycaemic. The mean glucose level in Kir6. $2^{-/-}$mice was $12.4 \pm 0.5 \mathrm{mM}(\mathrm{n}=26)$, while the mean glucose level in age-matched control C57/B6 mice was $8.5 \pm 0.2 \mathrm{mM}(\mathrm{n}=10 ; \mathrm{p}<0.001)$. This agedependent change in glucose homeostasis is in line with the previous evidence suggesting that it is caused by excessive $\beta$-cell death due to calcium toxicity or apoptosis [19].

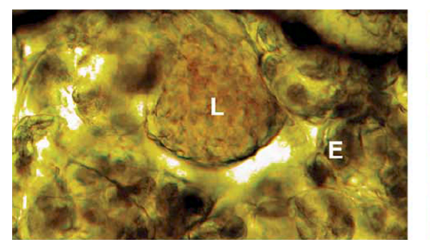

C57/B6, 2 weeks old

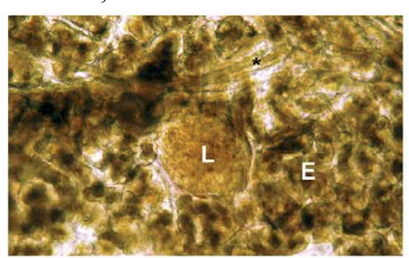

Kir6. $2^{-/-}, 2$ weeks old

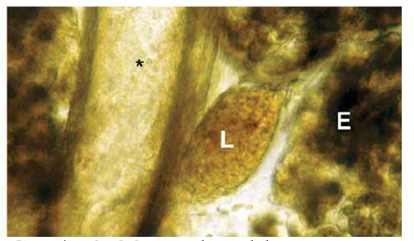

C57/B6, 30 weeks old

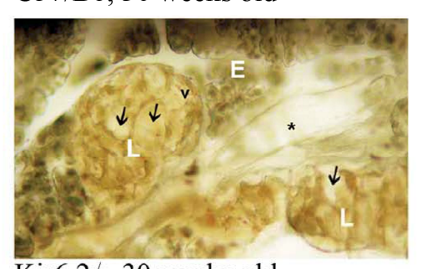

Kir6. $2^{-1}, 30$ weeks old

(a)

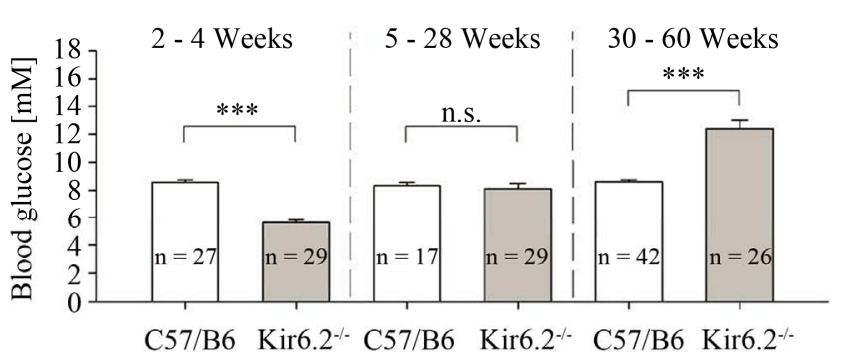

(b)

Figure 1. Transmitted light images of control C57/B6 and Kir6.2 $2^{-/-}$mice islets in fresh pancreatic tissue slices and random blood glucose measurements: (a) The upper images show islets in fresh tissue slices from 2 and 30 weeks old C57/B6 mice. Note the intact islets of Langerhans (L) surrounded by the exocrine pancreas tissue (E). Longitudinally or transversely cut vessels and ducts were observed in the majority of slices (asterisks). Young Kir6.2 $2^{-/-}$islets (lower left image) appeared intact and densely packed with cells, similar to control islets. Older islets (lower right) showed many hollow islets, containing connective tissue and few or no cells (arrows), with undefined borders and exposed fine vascularisation (v); (b) The random blood glucose measurement showed a transient mild hypoglycaemia in young Kir6. $2^{-/-}$mice that progressed to relative hyperglycaemia in adult Kir6. $2^{-/-}$mice (grey bars) compared to age-matched control mice (white bars). Numbers on bars indicate the number of mice for each experiment. n.s. $\mathrm{p}>0.05 ;{ }^{* * *} \mathrm{p}<0.001$. 


\subsection{Electrophysiological Characterization of $\beta$-Cells in Slices}

The $\beta$-cells have been identified using a standard protocol of 4 conditioning pre-pulses ranging from -150 to -40 $\mathrm{mV}$. The characteristic inactivation properties of voltage-activated $\mathrm{Na}^{+}$channels in $\beta$-cells were found to be fully inactivated at $-60 \mathrm{mV}$ (Figure 2(a)). An additional criterion for $\beta$-cell identification was the presence of gap junction conductance, with $\beta$-cells unlike non- $\beta$-cells expressing gap junction conductance (Figure 2(a)). The third criterion was the glucose sensitivity of the electrical activity (Figure 2(b), upper panel).

At low glucose concentrations ( $3 \mathrm{mM}$ ), wild-type $\beta$-cell syncytia are electrically silent with a resting membrane potential close to the equilibrium diffusion potential for $\mathrm{K}^{+}$[23]. At glucose levels above $6 \mathrm{mM}$, glucose-induced depolarization was sufficient to elicit repetitive bursting activity with action potentials superimposed on top of the bursts (Figure 2(b), upper panel). In contrast, Kir6.2 ${ }^{-1-}$ $\beta$-cell syncytia displayed the electrical activity already at non-stimulatory glucose concentration (3 $\mathrm{mM}$ ) (Figure 2(b), bottom panel). Moreover, at this low glucose concentration, $\beta$-cell syncitia showed both bursting and spiking activity (Figure 2(b), bottom panel inset). A major difference to wild-type syncytia is that action potentials were also present during the interburst periods. Addition of high glucose concentration to Kir6. $2^{-/-}$slices did not further alter their electrical activity pattern. Among the 80 tested control C57/B6 $\beta$-cell syncytia, none of the cells showed spiking electrical activity in $3 \mathrm{mM}$ glucose, while $82 \%$ of Kir $6.2^{-/} \beta$-cell syncytia showed both bursting as well as spiking activity at $3 \mathrm{mM}$ glucose. The presence of slow bursting in Kir6. $2^{-/} \beta$-cell syncytia implies that there are still ion channels other than $\mathrm{K}_{\text {ATP }}$ channel on the plasma membrane that influence the membrane potential fluctuations.
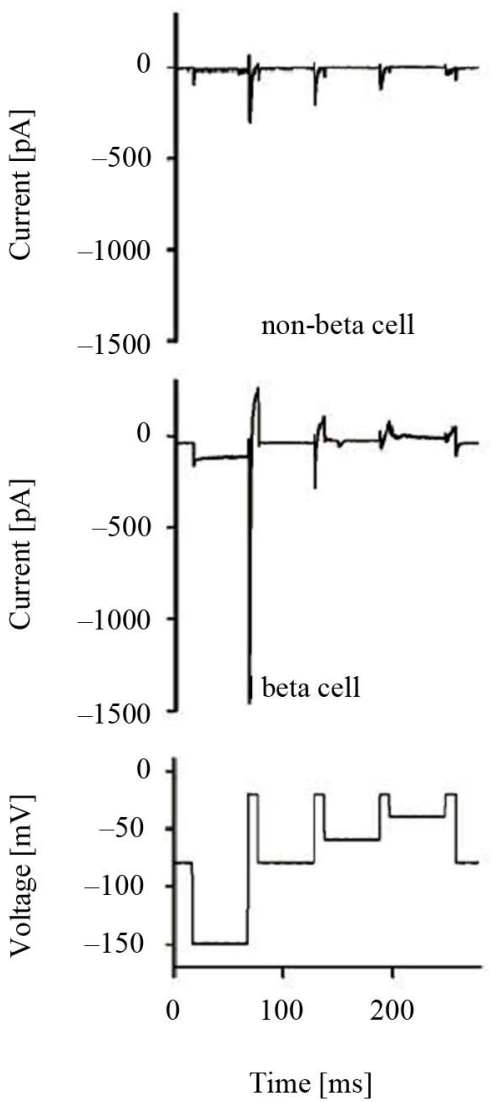

(a)
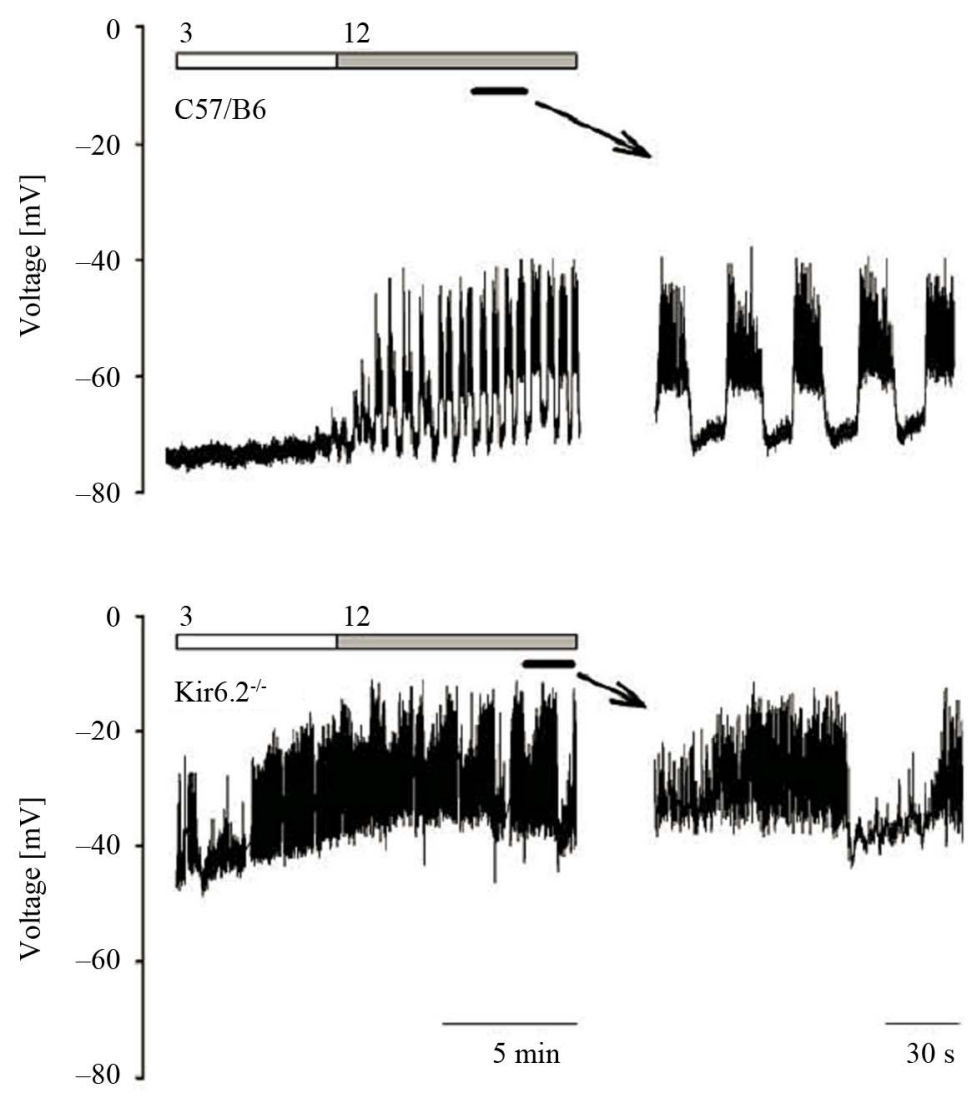

(b)

Figure 2. Cell identification and electrical activity in $\beta$-cells of control C57/B6 and Kir6. $2^{-/-}$mice: (a) $\beta$-cells were identified based on the steady state inactivation characteristics of voltage gated $\mathrm{Na}^{+}$currents, gap junction conductance and (b) electrical activity in the presence of increased glucose. At $3 \mathrm{mM}$ glucose, a control $\beta$-cell is electrically silent with a resting membrane potential of approximately $-70 \mathrm{mV}$. At glucose levels above $6 \mathrm{mM}$ electrical activity is initiated with its extent depending on the glucose concentration. In contrast, $\beta$-cells of Kir6. $2^{-/-}$were electrically active already at $3 \mathrm{mM}$ glucose. High glucose concentration did not independently alter the electrical activity in Kir6. $2^{-/}$mice. Note the oscillations of membrane potential in both cell types. Also note the individual electrical spikes between bursts of electrical activity in Kir6. $2^{-/} \beta$-cells (bottom panel). Numbers above bars indicate glucose concentration in $\mathrm{mM}$. 
Despite the overall increase in the size of the islets as the Kir6. $2^{-/}$mice become older, there was no significant difference in the $\beta$-cell size, measured as a resting membrane capacitance $\left(\mathrm{C}_{\mathrm{m}}\right)$, a measure of cell surface area, in $\beta$-cells of Kir6. $2^{-/}$mice compared to age matched $\beta$-cells in control C57/B6 mice (Figure 3(a)). The mean resting $\mathrm{C}_{\mathrm{m}}$ for Kir6. $2^{-/} \beta$-cells was $6.9 \pm 1.7 \mathrm{pF}(\mathrm{n}=45)$ and $6.7 \pm$ $1.3 \mathrm{pF}$ for control C57/B6 $\beta$-cells $(\mathrm{n}=28 ; \mathrm{p}=0.6)($ Figure 3(a)).

\subsection{Voltage-Activated $\mathrm{Ca}^{2+}$ Currents in Kir6.2 ${ }^{-/-}$ and Control C57/B6 $\beta$-Cells}

Insulin release from pancreatic $\beta$-cells is triggered by the entry of calcium ions through the VACCs. Modulation of the VACCs may therefore alter insulin exocytosis from $\beta$-cells [27]. We first compared the current size and current density of VACCs from $\beta$-cells of both genotypes. After subjection of the Kir6. $2^{-/}$and control C57/B6 $\beta$-cells to voltage ramps ranging from -80 to $60 \mathrm{mV}$ with a du- ration of $300 \mathrm{~ms}\left(0.47 \mathrm{mV} \cdot \mathrm{ms}^{-1}\right.$, Figure 3(b) 1) [28,29], two inward current components, showing peaks around -42 and $-5 \mathrm{mV}$ were identified (Figure 3(b) 2). These peaks corresponded to low (LVA) and high (HVA) voltage-activated $\mathrm{Ca}^{2+}$ currents. We found that Kir6. $2^{-/-} \beta$-cells had larger voltage-activated $\mathrm{Ca}^{2+}$ current amplitudes, despite the persistent electrical activity. The pooled peak HVA $\mathrm{Ca}^{2+}$ currents were $-175 \pm 17 \mathrm{pA}(\mathrm{n}=33)$ and $-101 \pm 6 \mathrm{pA}(\mathrm{n}=25 ; \mathrm{p}<0.001)$, for Kir6.2 ${ }^{-/ 2}$ and control C57/B6 $\beta$-cells, respectively (Figure 3(b) 3 , left). The pooled peak low-voltage activated (LVA) $\mathrm{Ca}^{2+}$ current amplitudes were $-117 \pm 12 \mathrm{pA}(\mathrm{n}=33)$ and $-64 \pm 5 \mathrm{pA}$ $(\mathrm{n}=25 ; \mathrm{p}<0.001)$ for Kir6. $2^{-/-}$and control C57/B6 $\beta$-cells, respectively (Figure 3(b) 4 , left). Since the cell size of $\beta$-cells of the two phenotypes were comparable, we concluded that the VACC current densities were significantly larger in Kir6. $2^{-/} \beta$-cells compared to control C57/B6 $\beta$-cells (Figure 3(b) 3, right and Figure 3(b) 4, right). These larger VACC currents may contribute to the hypoglycaemic phenotype in young Kir6. $2^{-/}$mice.
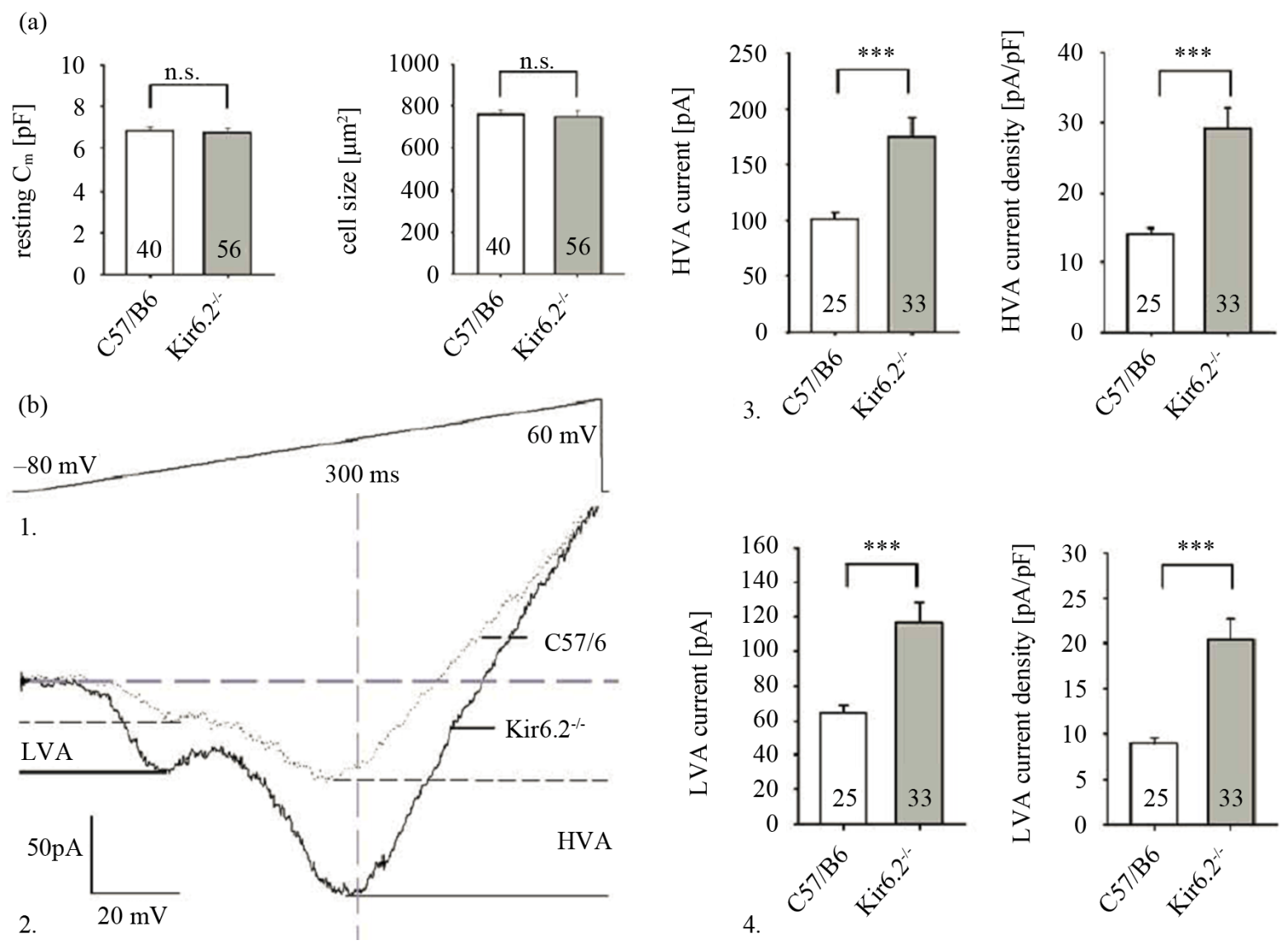

Figure 3. $\beta$-cell size and $\mathrm{Ca}^{2+}$ currents through VACC in control and Kir6. $2^{-/-}$mice. (a) There is no significant difference in $\beta$-cells' total surface area or initial $\mathrm{C}_{\mathrm{m}}$ of whole-cell patch-clamped $\beta$-cells of Kir6. $2^{-/-}$(gray bars) compared to control C57/B6 mice (white bars). (b) 1 . After subjection of $\beta$-cells to voltage ramps from -80 to $60 \mathrm{mV}$ with duration of $300 \mathrm{~ms}$ $(0.47 \mathrm{mV} / \mathrm{ms}) ; 2$. VACCs are readily activated in Kir6. $2^{-/-}$(black line) and control $\beta$-cells (dotted line); 3 . Peak HVA current and density and 4 . Peak LVA current and density in both phenotypes. Numbers on bars indicate the number of cells in each experiment. $\mathrm{p}<0.001$. 


\subsection{Stimulus-Secretion Coupling in $\beta$-Cells of Kir6.2 $^{-/-}$and Control C57/B6 Mice}

In the $\beta$-cells of Kir6. $2^{-/-}$mice we observed both hypoand hyperglycaemia, depending on the age of the animals. To check how modified function of the secretory machinery in the $\beta$-cells from Kir6. $2^{-/-}$animals may modify the glycaemia status in these animals, we performed a detailed examination of the stimulus-secretion coupling in both Kir6. $2^{-/-}$and control C57/B6 $\beta$-cells. We used depolarization protocols to assess the size of the pool of the vesicles that are ready to exocytose.

In the whole-cell voltage-clamp mode, we applied a train of 50 depolarizing pulses of $40 \mathrm{~ms}$ duration from -80 to $10 \mathrm{mV}$ at a frequency of $10 \mathrm{~Hz}$ (Figure 4(b) 1 , top trace). Figure 4(a) shows histograms of the total $C_{m}$ amplitude increase after such depolarizing train in control C57/B6 (Figure 4(a), right) and Kir6. $2^{-/-} \beta$-cells (Figure 4(a), left). The distribution of $\mathrm{C}_{\mathrm{m}}$ amplitudes from C57/B6 $\beta$-cells was unimodal peaking at about $100 \mathrm{fF}$. In contrast, the distribution of $\mathrm{C}_{\mathrm{m}}$ amplitudes from Kir6.2 $2^{-/-}$ $\beta$-cells was bimodal, indicating two major groups of cells. The first peak (98 fF) resembled to the peak of the control group, while the second peak $(251 \mathrm{fF})$ represented a subpopulation of $\beta$-cells with much larger capacitance increase (Figure 4(a), right). Retrograde analysis of other physiological parameters measured in this study showed that the $\beta$-cells that peaked at higher $\mathrm{C}_{\mathrm{m}}$ values were obtained from the hypoglycaemic mice typically younger than 4 weeks (Figure 4(b) 2). On the other hand, in $\beta$-cells from old hyperglycaemic Kir6.2 $2^{-/-}$mice the $C_{m}$ change has been significantly lower compared to the $\mathrm{C}_{\mathrm{m}}$ change in $\beta$-cells from hypoglycaemic younger Kir6. $2^{-/-}$mice (Figure 4(b) 4). Since we have noticed the heterogeneity of the depolarization train-induced $\mathrm{C}_{\mathrm{m}}$ changes in Kir6.2 $2^{-/-}$ $\beta$-cells, we clustered the data into two groups: young (2 4 weeks old) and adult (5 - 60 weeks old) mice and statistically compared both phenotypes. The $\mathrm{C}_{\mathrm{m}}$ changes were $110 \pm 20 \mathrm{fF}(\mathrm{n}=13)$ and $251 \pm 29 \mathrm{fF}(\mathrm{n}=16)$ for young control C57/B6 and Kir6.2 $2^{-/-}$, respectively (Figure 4(b) 4). These results indicate that the $\beta$-cells in young Kir6. $2^{-/-}$ mice may have a more efficient stimulus-secretion coupling than age-matched Kir6. $2^{+/+}$mice. This finding could partially explain the hypoglycaemic phenotype in young Kir6. $2^{-/-}$mice. These differences were not found in adult mice irrespective of the genetic background (Figure 4(b) 4).

\subsection{The Efficacy of $\mathrm{Ca}^{2+}$ to Trigger Secretion}

Kir6. $2^{-/} \beta$-cells displayed a constitutive excitability at nonstimulatory glucose levels (Figure 2(b), bottom panel). Calcium entry via VACCs has been suggested to be the major source of this ion to trigger exocytosis in $\beta$-cells [1]. High basal activity in Kir6. $2^{-/-} \beta$-cells may result in an elevated basal calcium levels and thus increase the efficacy with which $\mathrm{Ca}^{2+}$ ions regulate the exocytotic machinery to produce a higher $\mathrm{C}_{\mathrm{m}}$ change.

We quantified the calcium-dependent exocytotic efficacy in $\beta$-cells from both genotypes, since larger VACCs in $\beta$-cells from Kir6. $2^{-/-}$mice may mask the impaired exo cytotic machinery, as was the case in $\beta$-cells from Goto Kakizaki (GK) rats shown previously [28]. We found that, despite of larger VACC in Kir6. $2^{-/-} \beta$-cells, there was no difference in overall $\mathrm{Ca}^{2+}$ efficacy during the first train of depolarization compared to that of control C57/B6 $\beta$-cells. The mean efficacy $\left(\sum \Delta \mathrm{Cm} / \sum \Delta \mathrm{Q}\right)$ of the first trains were $3.4 \pm 0.3 \mathrm{fF} \mathrm{pC}^{-1}(\mathrm{n}=36)$ for Kir6. $2^{-/-}$ $\beta$-cells and $2.8 \pm 0.3 \mathrm{fF} \mathrm{pC}^{-1}(\mathrm{n}=23)$ for control C57/B6 $\beta$-cells (Figure 5(b) 3 ).

In addition, we also applied a second train of depolarization pulses 4 min after the first train to assess any kind of an activity-dependent augmentation in $\beta$-cells from Kir6. $2^{-/-}$due to residual $\mathrm{Ca}^{2+}$ from the first train [28]. In control C57/B6 $\beta$-cells, capacitance increases induced by the first and the second train were comparable in amplitude $115 \pm 13 \mathrm{fF}(\mathrm{n}=21)$ and $96 \pm 14 \mathrm{fF}(\mathrm{n}=21)$, respectively $(\mathrm{p}=0.33)$ (Figures 5(a) 1 and 3$)$, while in Kir6. $2^{-/-}$ $\beta$-cells, the second train of depolarization induced a much larger $\mathrm{C}_{\mathrm{m}}$ increase compared with the first train $124 \pm 17$ $\mathrm{fF}(\mathrm{n}=30)$ and $232 \pm 26 \mathrm{fF}(\mathrm{n}=30)$, respectively; $\mathrm{p}<$ 0.001, (Figures 5(a) 2 and 3). Not surprisingly, for the second train of depolarization, the efficacy was higher in Kir6. $2^{-/-} \beta$-cells compared to control C57/B6 $\beta$-cells (3.3 $\pm 0.5 \mathrm{fF} \mathrm{pC} \mathrm{pC}^{-1}(\mathrm{n}=21)$ for control C57/B6 and $6.9 \pm 0.7$ $\mathrm{fF}^{-1}(\mathrm{n}=32)$ for Kir6.2 ${ }^{-/-}$(Figures 5(b) 1 and 3).

\section{DISCUSSION}

A Kir6. $2^{-/-}$mice have been originally produced as an animal model for congenital hyperinsulinaemia. The main novelty of this study is that we assessed the physiology of Kir6. $2^{-/-} \beta$-cells in fresh pancreatic slice preparation in which cell-to-cell contacts, intercellular communication and tissue architecture are well preserved. In this study, we conclude that despite the predicted depolarized membrane potential in Kir6. $2^{-/} \beta$-cells, both the functional expression of VACCs as well as modified exocytotic efficacy contribute to the observed age-dependent reduction of the $\beta$-cell activity. These results may help us to better understand the pathophysiology of PHHI in human patients. More importantly, despite the fact that the expression of the $\mathrm{K}_{\mathrm{ATP}}$ channels in $\beta$-cells seems to be the key element connecting glucose metabolism to insulin release, the loss of function mutations of the $\mathrm{K}_{\mathrm{ATP}}$ channels or complete absence of the $\mathrm{K}_{\mathrm{ATP}}$ channels may have an impact on time-dependency in the development of the phenotype. This time-dependent component should be considered in the design of the less robust therapeutic strategies for PHHI patients and other related human diseases. 


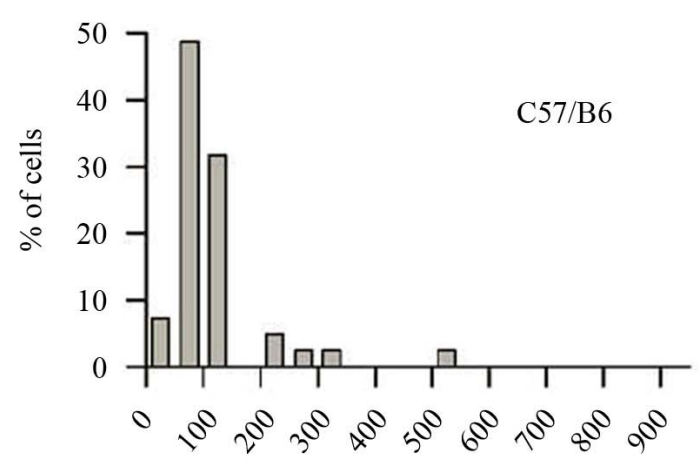

capacitance $[\mathrm{fF}]$

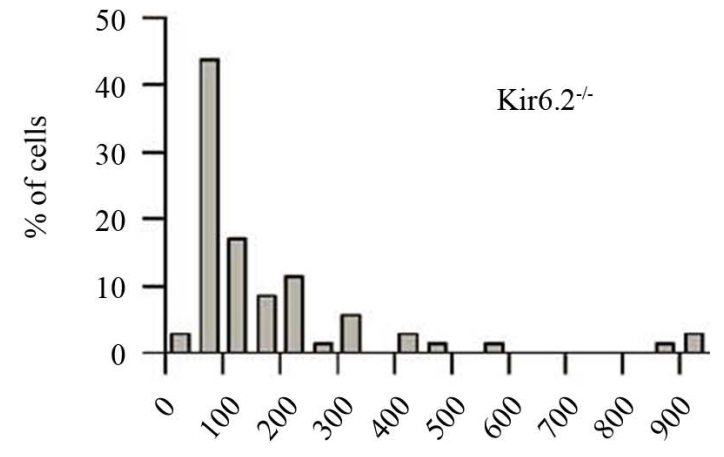

capacitance $[\mathrm{fF}]$

(a)
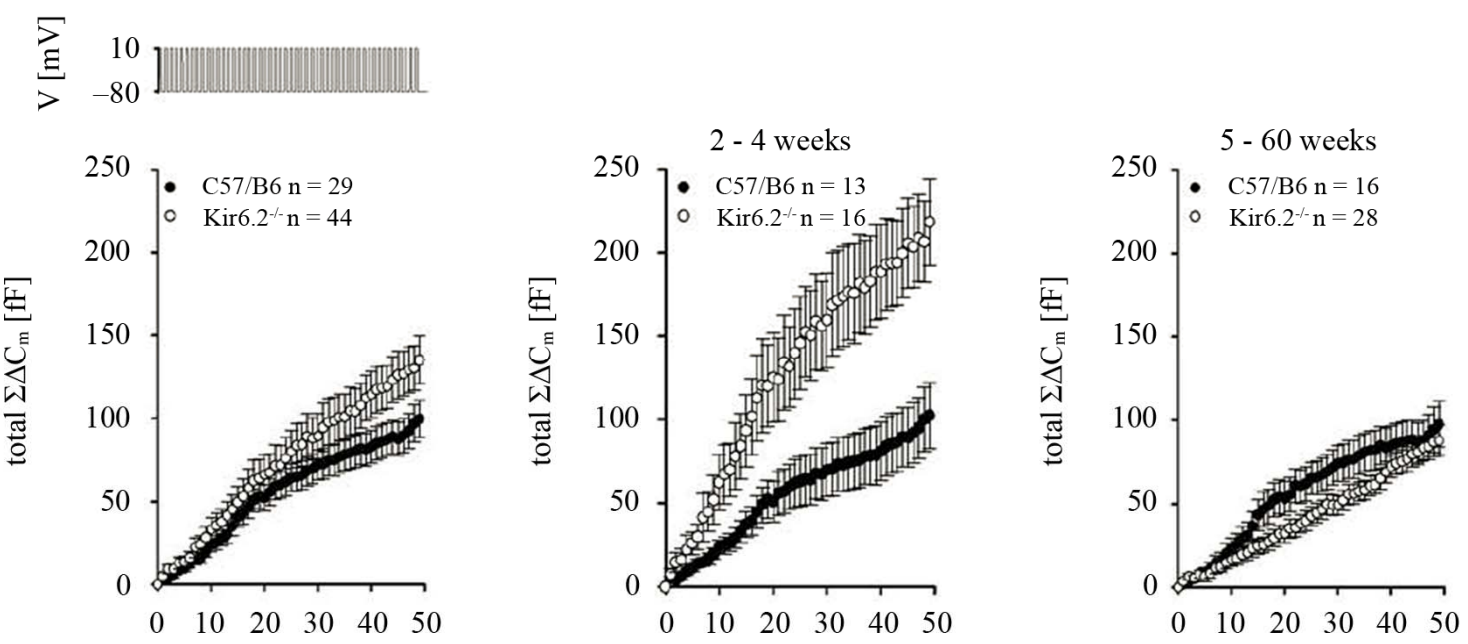

1.

pulse \#

2.

pulse \#

3.

pulse \#
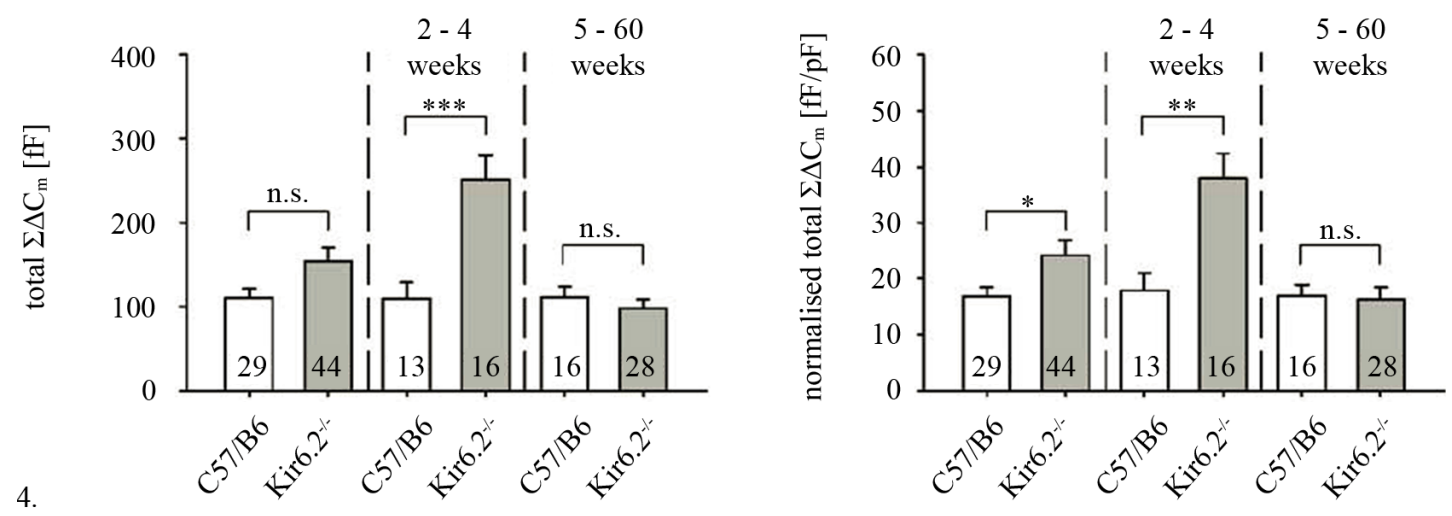

(b)

Figure 4. Stimulus-secretion coupling in $\beta$-cells of control and Kir6. $2^{-/-}$mice. (a) Histogram of the total capacitance change in $\beta$-cells of control and Kir6.2 $2^{-/}$mice after a depolarization train; (b) 1-3, Depolarization train-induced changes in $\mathrm{C}_{\mathrm{m}}$ in $\beta$-cells of control and Kir6.2 $2^{-/}$mice, obtained by subjecting $\beta$-cells to a train of 50 depolarisation pulses of $40 \mathrm{~ms}$ duration from -80 to $10 \mathrm{mV}$ at a frequency of $10 \mathrm{~Hz}$; 1 . An average $\Sigma \Delta \mathrm{C}_{\mathrm{m}}$ during 50 depolarizationstrain of control (closed circles) and Kir6. $2^{-/-}$(open circles); 2. However, after separation into different age-groups, there was a significant difference between control (open circles) and Kir6. $2^{-/-} \beta$-cells (closed circles) in a group of 2 4 weeks old mice; 3 . The group of 5 - 60 weeks old mice showed no differences; 4 . The comparison of total $\Sigma \Delta C_{m}$ at the end of depolarization train (left) and total $\Sigma \Delta \mathrm{C}_{\mathrm{m}}$ normalised to cell size (right) between control $\beta$-cells (open bars) and Kir6. $2^{-/-} \beta$-cells (closed bars) in different age groups as indicated. Numbers on bars indicate the number of mice for each experiment. $\mathrm{p}>0.05$; n.s. ${ }^{*} \mathrm{p}<0.05 ;{ }^{* *} \mathrm{p}<0.002 ;{ }^{* * *} \mathrm{p}<0.001$. 

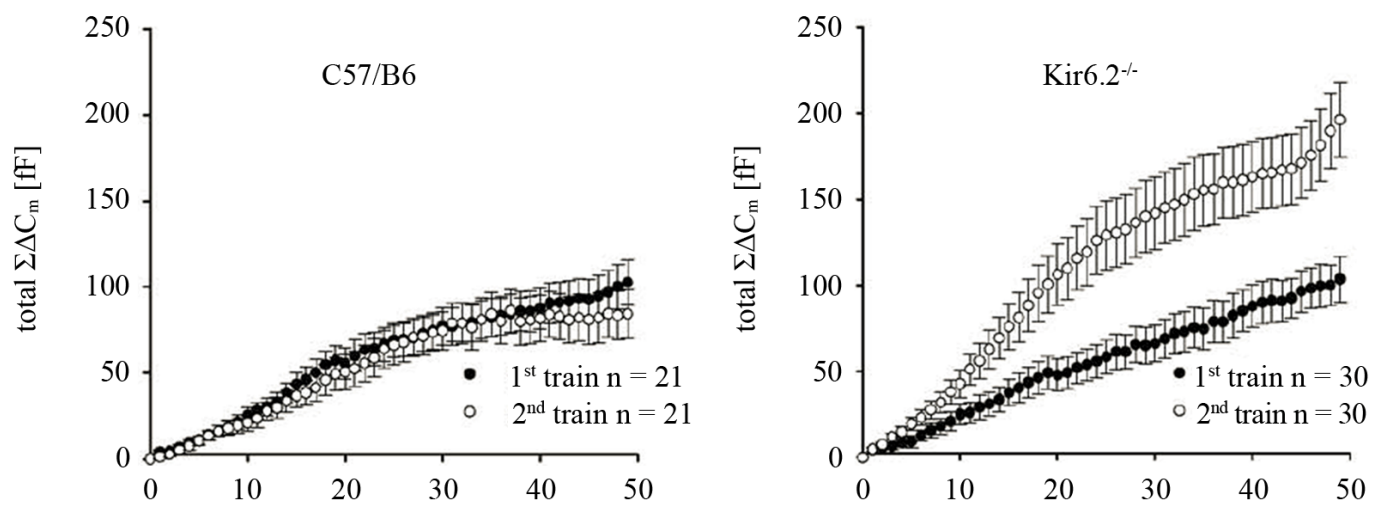

1.

Pulse \#

2.

Pulse \#
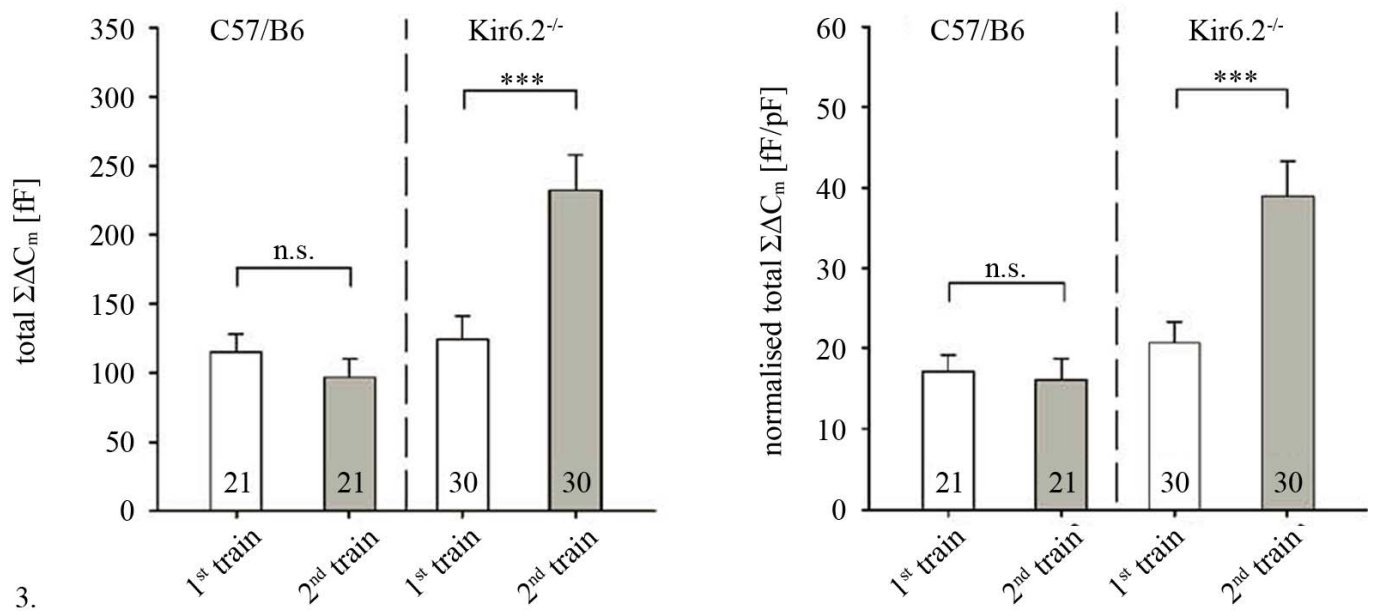

(a)

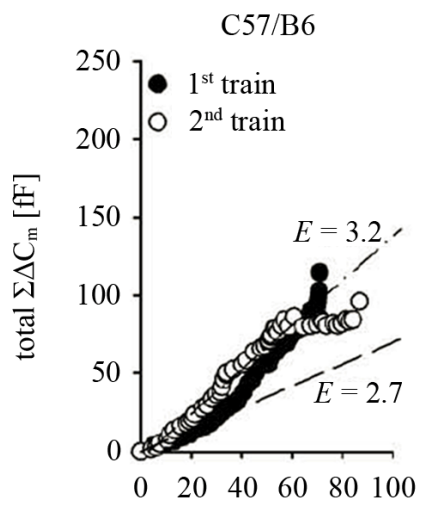

1.

$$
\Sigma \mathrm{Q}_{\mathrm{Ca}^{2+}}[\mathrm{pC}]
$$

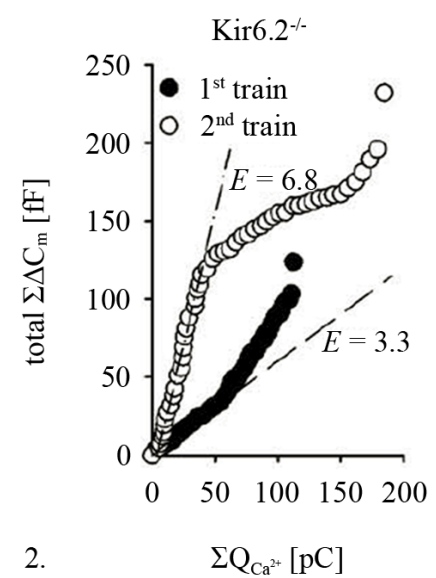

(b)

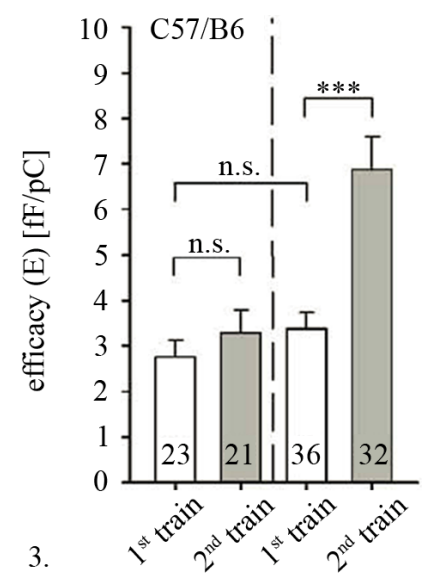

Figure 5. Secretion in $\beta$-cells during sequential depolarization train and calcium efficacy (E). (a) The average $\Sigma \Delta \mathrm{C}_{\mathrm{m}}$ in response to two successive depolarization trains in 1 . control and 2 . Kir6.2 $\beta$-cells, respectively ( 4 min interval between the trains). 3. comparison of the total $\Sigma \Delta \mathrm{C}_{\mathrm{m}}$ reached after the end of the train (left) and total $\Sigma \Delta \mathrm{C}_{\mathrm{m}}$ normalized to cell size (right) between control (open bars) and Kir6. $2^{-/-}$ (close bars) $\beta$-cells. Note the significant difference in total $\Sigma \Delta \mathrm{C}_{\mathrm{m}}$ between the successive trains in Kir6. $2^{-/-}$ $\beta$-cells; (b) Representative $\Sigma \Delta \mathrm{C}_{\mathrm{m}}$ as a function of $\Sigma \Delta \mathrm{QCa}^{2+}$ of 1 . control and 2 . Kir6. $2^{-/-} \beta$-cells, respectively. Straight lines represent linear fits through the first 10 data points (efficacy) of the 1 st (dashed) and 2nd train (dot-dashed). 3. the average efficacy (E) of 1st and 2nd trains of control (left) and Kir6. $2^{-/-}$ $\beta$-cells (right). Note the significant difference between both trains in Kir6. $2^{-/-} \beta$-cells. Numbers on bars indicate the number of cells in each experiment. n.s. $p>0.05 ;{ }^{* * *} \mathrm{p}<0.001$. 
The gross appearance and the density of the $\beta$-cell packing in Kir6. $2^{-/-}$mice younger than 4 weeks did not differ from the islets from control C57/B6 mice (Figure 1(a)). This result implies that $\mathrm{K}_{\mathrm{ATP}}$ channels are not critical in the early postnatal morphogenesis, however on the longterm they seem to be indispensable for the survival of insulin-secreting $\beta$-cells. This is in agreement with previous studies that showed that hyperexcitability of the Kir6. $2^{-/} \beta$-cells may result in cell death or apoptosis due to calcium toxicity in aged mice [19].

Random blood glucose measurements in Kir6. $2^{-/-}$mice showed a transient hypoglycaemia in young Kir6. $2^{-/}$mice ( 2 - 4 weeks old), normoglycaemia in young adult mice (5 - 28 weeks old), and a mild hyperglycaemia in aged mice (30 - 60 weeks old). Similar age dependencies have been shown in previous studies $[19,20,22]$. These changes are also likely to be caused by a reduction of $\beta$-cell mass in aged Kir6. $2^{-/-}$mice. As reported previously, also our colony of Kir6. $2^{-/}$mice were obese as they became older [30].

At present, little is known about the role of the $\mathrm{K}_{\mathrm{ATP}}$ channels in $\beta$-cell exocytosis. This report is the first attempt to assess complete lack of the $\mathrm{K}_{\mathrm{ATP}}$ channels in this physiological process using pancreatic slice preparation. Capacitance measurements have been used in several experiments as secretory assay by indirectly measuring exo- and endocytosis involved in hormone secretion $[23,28,31,32]$. In Kir6. $2^{-/}$mice we found two subpopulations of $\beta$-cells; however it turned out that the smaller subpopulation which has shifted towards excessive $C_{m}$ change in response to a train of depolarization pulses belonged exclusively to Kir6. $2^{-/}$mice younger than 4 weeks which were hypoglycaemic (Figure 4(b) 2). On the other hand, there were no significant differences in $\mathrm{C}_{\mathrm{m}}$ changes between the $\beta$-cells from the adult mice (Figure 4(b) 3).

The excessive $C_{m}$ response may be due to several reasons. First, in all insulin secreting cells from different rodent species tested so far, the $\mathrm{Ca}^{2+}$-influx is mainly mediated by high voltage activated (HVA) L-type $\mathrm{Ca}^{2+}$ channels, either Cav1.2 or Cav1.3 channels [33]. In this study, we noticed a significantly larger HVA and LVA peak currents in Kir6. $2^{-/}$compared to control C57/B6 $\beta$-cells. Constitutive electrical activity, even in the presence of non-stimulatory glucose concentration and larger HVA current amplitude measured in Kir6. $2^{-/} \beta$-cells may be the cause of an elevated basal $\left[\mathrm{Ca}^{2++}\right]_{\mathrm{i}}$ measured in previous experiment [21]. Second, as in the fresh pancreatic slice preparation of GK rat $\beta$-cells [28], we found that $\mathrm{C}_{\mathrm{m}}$ increase elicited by the second train of depolarizations had a significantly higher efficacy in $\operatorname{Kir} 6.2^{-/-} \beta$ cells compared to control C57/B6, where this activity dependent augmentation did not take place (Figure 5(b)).

The question remains, why are the adult Kir6. $62^{-/-}$mice normoglycaemic and in the last part of life even hyperglycaemic? The changed morphological features and pre- viously published evidence suggest that this is mainly due to a progressively decreasing population of $\beta$-cells with increasing age in Kir6. $2^{-/}$. In addition, many $\beta$-cells from aged Kir6. $2^{-/}$mice did not respond to a train of depolarizations indicating that there is an additional lesion in the secretory machinery.

\section{ACKNOWLEDGEMENTS}

We thank Marion Niebeling, Heiko Röhse and Rudi Mlakar for excellent technical support. Part of the work was financed by the Growbeta EU grant (5th framework, No. QLG1-CT-2001-02233). The European Neuroscience Institute Göttingen (ENI-G) is jointly funded by the Göttingen University Medical School, the Max-Planck-Society and Schering AG. MR is supported from the The Slovenian Research Agency (J3-7186-2334).

\section{REFERENCES}

[1] Ashcroft, F.M. and Rorsman, P. (1990) ATP-sensitive $\mathrm{K}^{+}$ channels: A link between B-cell metabolism and insulin secretion. Biochemical Society transactions, 18, 109-111.

[2] Maechler, P., Kennedy, E.D., Sebo, E., Valeva, A., Pozzan, T. and Wollheim, C.B. (1999) Secretagogues modulate the calcium concentration in the endoplasmic reticulum of insulin-secreting cells. Studies in aequorin-expressing intact and permeabilized ins-1 cells. The Journal of Biological Chemistry, 274, 12583-12592 doi:10.1074/jbc.274.18.12583

[3] Ammala, C., Eliasson, L., Bokvist, K., Larsson, O., Ashcroft, F.M. and Rorsman, P. (1993) Exocytosis elicited by action potentials and voltage-clamp calcium currents in individual mouse pancreatic B-cells. The Journal of Physiology, 472, 665-688.

[4] Inagaki, N., Gonoi, T., Clement, J.P., et al. (1995) Reconstitution of IKATP: An inward rectifier subunit plus the sulfonylurea receptor. Science, 270, 1166-1170. doi:10.1126/science.270.5239.1166

[5] Shyng, S. and Nichols, C.G. (1997) Octameric stoichiometry of the KATP channel complex. The Journal of General Physiology, 110, 655-664. doi:10.1085/jgp.110.6.655

[6] Aguilar-Bryan, L., Nichols, C.G., Wechsler, S.W., et al. (1995) Cloning of the beta cell high-affinity sulfonylurea receptor: A regulator of insulin secretion. Science, $\mathbf{2 6 8}$, 423-426. doi:10.1126/science.7716547

[7] Schwappach, B., Zerangue, N., Jan, Y.N. and Jan, L.Y. (2000) Molecular basis for K(ATP) assembly: Transmembrane interactions mediate association of a $\mathrm{K}^{+}$channel with an ABC transporter. Neuron, 26, 155-167. doi:10.1016/S0896-6273(00)81146-0

[8] Zerangue, N., Schwappach, B., Jan, Y.N. and Jan, L.Y. (1999) A new ER trafficking signal regulates the subunit stoichiometry of plasma membrane K(ATP) channels. Neuron, 22, 537-548. doi:10.1016/S0896-6273(00)80708-4

[9] Inagaki, N., Gonoi, T., Clement, J.P., et al. (1996) A 
family of sulfonylurea receptors determines the pharmacological properties of ATP-sensitive $\mathrm{K}^{+}$channels. Neuron, 16, 1011-1017. doi:10.1016/S0896-6273(00)80124-5

[10] Speier, S., Yang, S.B., Sroka, K., Rose, T. and Rupnik, M. (2005) KATP-channels in beta-cells in tissue slices are directly modulated by millimolar ATP. Molecular and Cellular Endocrinology, 230, 51-58. doi:10.1016/j.mce.2004.11.002

[11] Ashcroft, F.M. and Rorsman, P. (2004) Molecular defects in insulin secretion in type-2 diabetes. Reviews in Endocrine \& Metabolic Disorders, 5, 135-142. doi:10.1023/B:REMD.0000021435.87776.a7

[12] Gloyn, A.L., Reimann, F., Girard, C., et al. (2005) Relapsing diabetes can result from moderately activating mutations in KCNJ11. Human Molecular Genetics, 14, 925-934. doi:10.1093/hmg/ddi086

[13] Koster, J.C., Permutt, M.A. and Nichols, C.G. (2005) Diabetes and insulin secretion: The ATP-sensitive $\mathrm{K}^{+}$ channel (K ATP) connection. Diabetes, 54, 3065-3072. doi:10.2337/diabetes.54.11.3065

[14] Babenko, A.P., Polak, M., Cave, H., et al. (2006) Activating mutations in the $\mathrm{ABCC} 8$ gene in neonatal diabetes mellitus. The New England Journal of Medicine, 355, 456-466. doi:10.1056/NEJMoa055068

[15] Huopio, H., Shyng, S.L., Otonkoski, T. and Nichols, C.G. (2002) K(ATP) channels and insulin secretion disorders. American Journal of Physiology-Endocrinology and Metabolism, 283, E207-E216.

[16] Lin, Y.W., Bushman, J.D., Yan, F.F., et al. (2008) Destabilization of ATP-sensitive potassium channel activity by novel KCNJ11 mutations identified in congenital hyperinsulinism. The Journal of Biological Chemistry, 283, 9146-9156. doi:10.1074/jbc.M708798200

[17] Nichols, C.G., Shyng, S.L., Nestorowicz, A., et al. (1996) Adenosine diphosphate as an intracellular regulator of insulin secretion. Science, 272, 1785-1787. doi:10.1126/science. 272.5269 .1785

[18] Aynsley-Green, A., Hussain, K., Hall, J., et al. (2000) Practical management of hyperinsulinism in infancy. Archives of Disease in Childhood - Fetal and Neonatal Edition, 82, F98-F107. doi:10.1136/fn.82.2.F98

[19] Miki, T., Nagashima, K., Tashiro, F., et al. (1998) Defective insulin secretion and enhanced insulin action in KATP channel-deficient mice. Proceedings of the $\mathrm{Na}$ tional Academy of Sciences, 95, 10402-10406. doi:10.1073/pnas.95.18.10402

[20] Remedi, M.S., Rocheleau, J.V., Tong, A., et al. (2006) Hyperinsulinism in mice with heterozygous loss of K(ATP) channels. Diabetologia, 49, 2368-2378. doi:10.1007/s00125-006-0367-4

[21] Seino, S., Iwanaga, T., Nagashima, K. and Miki, T. (2000) Diverse roles of K(ATP) channels learned from Kir6.2 genetically engineered mice. Diabetes, 49, 311-318. doi:10.2337/diabetes.49.3.311
[22] Winarto, A., Miki, T., Seino, S. and Iwanaga, T. (2001) Morphological changes in pancreatic islets of KATP channel-deficient mice: The involvement of KATP channels in the survival of insulin cells and the maintenance of islet architecture. Archives of Histology and Cytology, 64, 59-67. doi:10.1679/aohc.64.59

[23] Speier, S. and Rupnik, M. (2003) A novel approach to in situ characterization of pancreatic beta-cells. Pflugers Archiv: European Journal of Physiology, 446, 553-558.

[24] Dean, P.M. and Matthews, E.K. (1968) Electrical activity in pancreatic islet cells. Nature, 219, 389-390. doi: $10.1038 / 219389 \mathrm{a} 0$

[25] Huang, Y.C., Rupnik, M. and Gaisano, H.Y. (2011) Unperturbed islet alpha-cell function examined in mouse pancreas tissue slices. The Journal of Physiology, 589, 395-408. doi:10.1113/jphysiol.2010.200345

[26] Speier, S., Gjinovci, A., Charollais, A., Meda, P. and Rupnik, M. (2007) Cx36-mediated coupling reduces betacell heterogeneity, confines the stimulating glucose concentration range, and affects insulin release kinetics. Diabetes, 56, 1078-1086. doi:10.2337/db06-0232

[27] Gopel, S., Zhang, Q., Eliasson, L., et al. (2004) Capacitance measurements of exocytosis in mouse pancreatic alpha-, beta- and delta-cells within intact islets of Langerhans. The Journal of Physiology, 556, 711-726. doi:10.1113/jphysiol.2003.059675

[28] Rose, T., Efendic, S. and Rupnik, M. (2007) $\mathrm{Ca}^{2+}$-Secretion coupling is impaired in diabetic Goto Kakizaki rats. The Journal of General Physiology, 129, 493-508. doi:10.1085/jgp.200609604

[29] Sedej, S., Tsujimoto, T., Zorec, R. and Rupnik, M. (2004) Voltage-activated $\mathrm{Ca}^{2+}$ channels and their role in the endocrine function of the pituitary gland in newborn and adult mice. The Journal of Physiology, 555, 769-782. doi:10.1113/jphysiol.2003.058271

[30] Kanezaki, Y., Obata, T., Matsushima, R., et al. (2004) $\mathrm{K}(\mathrm{ATP})$ channel knockout mice crossbred with transgenic mice expressing a dominant-negative form of human insulin receptor have glucose intolerance but not diabetes. Endocrine Journal, 51, 133-144. doi: $10.1507 /$ endocrj. 51.133

[31] Sedej, S., Rose, T. and Rupnik, M. (2005) cAMP increases $\mathrm{Ca}^{2+}$-dependent exocytosis through both PKA and Epac2 in mouse melanotrophs from pituitary tissue slices. The Journal of Physiology, 567, 799-813. doi:10.1113/jphysiol.2005.090381

[32] Skelin, M. and Rupnik, M. (2011) cAMP increases the sensitivity of exocytosis to $\mathrm{Ca}^{2+}$ primarily through protein kinase A in mouse pancreatic beta cells. Cell Calcium, 49, 89-99. doi:10.1016/j.ceca.2010.12.005

[33] Barg, S., Eliasson, L., Renstrom, E. and Rorsman, P. (2002) A subset of 50 secretory granules in close contact with L-type $\mathrm{Ca}^{2+}$ channels accounts for first-phase insulin secretion in mouse beta-cells. Diabetes, 51, S74-S82. doi:10.2337/diabetes.51.2007.S74 